\title{
Effect of Tillage Practices and Moisture Regimes on the Performance of Growth, Yield and Nutrient Uptake of Timely Sown Wheat (Triticum aestivum L.)
}

\author{
Vinay Kumar Pandey*, B.N. Singh, Manoj Kumar, Shrimannarayan Dubey, \\ Vipul Singh, Deepak Pandey and Ajit Kumar
}
Department of Agronomy, Narendra Deva University of Agricultural \& Technology, Kumarganj, Faizabad, Uttar Pradesh-224229, India

*Corresponding author

\section{Keywords \\ Tillage practices, Moisture regimes, Growth, Yield, Nutrient uptake \\ Article Info \\ Accepted: \\ 20 February 2019 \\ Available Online: \\ 10 March 2019}

\section{A B S T R A C T}

The experiment was conducted during rabi season 2015-16 and 2016-17. The present investigation entitled "Effect of Tillage Practices and Moisture Regimes on the Performance of Wheat" was conducted at Agronomy Research Farm, of Narendra Deva University of Agriculture and Technology, Narendra Nagar (Kumarganj) Faizabad (U.P.). The experiment was laid out in split plot design having four tillage practices (zero tillage, reduced tillage+sowing by seed cum ferti drill, conventional tillage+sowing on beds and conventional tillage+ sowing by seed cum ferti drill) as main plot treatments and five moisture regimes (irrigation at $0.8 \mathrm{IW} / \mathrm{CPE}$, irrigation at $1.0 \mathrm{IW} / \mathrm{CPE}$ and irrigation at 1.2 IW/CPE irrigation at 3 Irrigation each at CRI, Late jointing and Milking stage and 5 Irrigation each at CRI, Tillering, Late jointing, Flowering and Milking stage) as sub plot treatments. 20 treatment combinations were replicated three times. The result revealed that the growth, yield and nutrient uptake were recorded significantly higher in conventional tillage + sowing on bed, which was at par with conventional tillage+ sowing by seed cum ferti drill during both the years due to performance of tillage practices. However, the growth, yield and nutrient uptake were significantly higher under irrigation at $1.0 \mathrm{IW} / \mathrm{CPE}$ being at par with 1.2 IW/CPE ratio and 5 Irrigation each at CRI, tillering, late jointing, flowering and milking stage over rest of the treatments causes optimum availability of moisture at critical stage of the crop growth.

\section{Introduction}

Wheat (Triticum aestivum L.) is one of the most important cereal crop belong to the family Poaceae, in the world. In India wheat is the second most important food crop next to rice and it contributes nearly $35 \%$ to the national food basket. Among winter crops, it contributes about $49 \%$ of the food grains. In India, total area under wheat is $31.72 \mathrm{~m}$ ha with the production and productivity of $96.0 \mathrm{~m}$ tonnes and 3.13 tonnes $\mathrm{ha}^{-1}$, respectively. It ranks first in the world among the cereals both in respect of area $(225.07 \mathrm{~m} \mathrm{ha})$ and 
production (736.98 mt) (USDA, 2017). In India, total production of wheat crop was $86.53 \mathrm{mt}$ from an covered area of $30.23 \mathrm{~m}$ ha during the recent past 2015-16 Rabi season and accounts for 38 per cent $4^{\text {th }}$ Advance Estimates. (Directorate of Economics and Statistics, Ministry of agriculture and farmers Welfare, India, 2016).Major wheat producing countries in the world are China, India USA, France, Russia, Canada, Australia, Pakistan, Turkey, UK, Argentina, Iran and Italy. These countries contribute about $76 \%$ of the total world wheat production. As far India is concerned, about $91 \%$ of the total wheat production is contributed by northern states. In India, the state wise production tops with of the Uttar Pradesh $26.87 \mathrm{mt}$, followed by Madhya Pradesh 17.69 mt, Punjab 16.08 mt, Haryana $11.35 \mathrm{mt}$, Rajasthan $9.87 \mathrm{mt}$, and Bihar $4.75 \mathrm{mt}$. These top six states together contributed about 93 per cent of the total wheat production.

Tillage is practiced in soils for controlling weeds, breaking crusts (improving water entry), increasing surface roughness (assisting water storage) and preparing a seedbed. The type of tillage method to be practiced, however, depends upon the soil type and the climate of the area (Coughlan et al., 1989). Various techniques viz., zero-tillage (ZT) and bed planting have proved to be beneficial in terms of improving soil health, water use and crop productivity (Anonymous, 1995). ZT is widely adopted by farmers in the Northwestern Indo-Gangetic plain of India, particularly in areas where rice is harvested late (Bhushan et al., 2007). It reduces irrigation requirements compared with conventional-tillage by using residual water more effectively (Erenstein et al., 2007). Bed planting, another RCT, has benefits like reduced seed rate, rainwater conservation, mechanical weeding and less crop lodging (Gupta and Seth, 2007). Water is an important input for realizing high wheat productivity; however, it is becoming the most limiting factor for crop production in most of the north western parts of India (Hira, 2009). Irrigation water is a major constraint for assumed crop production. To grow wheat economically and successfully the evapo-transpirative demand must be balanced with supply of available to it. Proper scheduling of irrigation (amount and timing) is an important component of water saving techniques. There are numerous ways to schedule irrigations and estimate the required depth of water application Prihar et al., 1997).

\section{Materials and Methods}

The present investigation entitled "Effect of Tillage Practices and Moisture Regimes on the Performance of Wheat" was carried at Agronomy Research Farm, of Narendra Deva University of Agriculture and Technology, Narendra Nagar Kumarganj, Faizabad (U.P.) out of during Rabi season, 2015-2016 and 2016-17. The experiment was constituted with 20 treatment involving four tillage practices in main plot and five irrigation levels in sub plot was laid out in split plot design with three replications. The experiment was laid out in given following viz., tillage practices mention are: $\quad \mathrm{T}_{1}$-Zero tillage, $\mathrm{T}_{2}$-Reduced tillage+sowing by seed cum ferti drill, $\mathrm{T}_{3}-$ Conventional tillage+ sowing on beds and $\mathrm{T}_{4}-$ Conventional tillage+ sowing by seed cum ferti drill as main plot treatment and five irrigation levels $\mathrm{I}_{1}$-Irrigation at $0.8 \mathrm{IW} / \mathrm{CPE}$, $\mathrm{I}_{2}$-Irrigation at $1.0 \mathrm{IW} / \mathrm{CPE}, \mathrm{I}_{3}$-Irrigation at 1.2 IW/CPE, I I $_{4}$ Irrigation each at CRI, Late jointing and Milking stage and $\mathrm{I}_{5}-5$ Irrigation each at CRI, Tillering, Late jointing, Flowering and Milking stage as sub plot treatment. Wheat was sown on $15^{\text {th }}$ November during in both years (2015-16 and 2016-17) at with a row spacing of $20 \mathrm{~cm}$ with seed cum ferti drill. Recommended dose of fertilizer $\mathrm{N}: \mathrm{P}: \mathrm{K}$ 120:60:40 $\mathrm{kg} \mathrm{ha} \mathrm{ha}^{-1}$ gave in crop. Uniform dose of nitrogen $60 \mathrm{~kg} \mathrm{ha}^{-1}$ through 
urea, phosphorus@ @60 kg ha ${ }^{-1}$ through diammonium phosphate and potassium @ $40 \mathrm{~kg}$ $\mathrm{ha}^{-1}$ through muriate of potash $60 \%\left(\mathrm{~K}_{2} \mathrm{O}\right)$ were applied to all treatments as basal dressing. Remaining half and 1/3 quantity of nitrogen was top dressed at CRI and tillering stage. Experimental field was slit loam in texture with low organic carbon (0.381 0 . $0.421 \%)$, low nitrogen (160.27 and $165.53 \mathrm{~kg}$ $\mathrm{ha}^{-1}$ ), and medium in phosphorus (16.83 and $17.78 \mathrm{~kg} \mathrm{ha}^{-1}$ ) and high range in potassium (258.57 and $265.27 \mathrm{~kg} \mathrm{ha}^{-1}$ ).

The variety was sown PBW-502. Ii is widely adopted in the area NWPZ. This variety may be grown in Entire North East India of India. It gives an average yield of 46-50 $\mathrm{q} \mathrm{ha}^{-1}$. Effective tillers were observed in running meter, and then converted values in square meter. The straw yield was computed by deducting the grain yield from the total biological yield and the grain yield data were adjusted at $14 \%$ moisture content. Statistical significance between mean differences among the treatment for different parameter was analyzed using the critical differences (CD) at $0.05 \%$ probability level.

\section{Results and Discussion}

The experimental results presented in the previous chapter contained the detailed information on study entitled "Effect of Tillage Practices and Moisture Regimes on the Performance of Wheat." to find out the suitable tillage practice and moisture regime for wheat production given following result and discussion below:

\section{Effect of tillage practices on growth and yield}

Initial plant population taken at 15 days after sowing was not influenced due to tillage practices. It was possibly due to favorable and similar soil and moisture condition for germination of seed in all treatments. This was mainly due to the fact that initial plant population was conducted at 15 DAS and irrigation treatments were not applied up-to this period.

Maximum initial plant population was recorded 133.35 and 134.14 plants $\mathrm{m}^{-2}$ in conventional tillage + sowing on beds $\left(\mathrm{T}_{3}\right)$ which was at par with conventional tillage+ sowing by seed cum ferti drill $\left(\mathrm{T}_{4}\right)$ and reduced tillage + sowing by seed cum ferti drill $\left(\mathrm{T}_{2}\right)$ respectively. Maximum plant height $(\mathrm{cm})$, number of shoots $\mathrm{m}^{-2}$ and dry matter accumulation $\left(\mathrm{gm} \mathrm{m}^{-2}\right)$ at harvest stage significant was recorded treatment under conventional tillage + sowing on beds $\left(\mathrm{T}_{3}\right)$ which was at par with conventional tillage+ sowing by seed cum ferti drill $\left(\mathrm{T}_{4}\right)$ and reduced tillage + sowing by seed cum ferti drill $\left(\mathrm{T}_{2}\right)$ respectively, during both the years.

However, the lowest all the parameters were recorded under treatments zero tillage $\left(\mathrm{T}_{1}\right)$ (Khatri et al., 2002; Ishaq and Ibrahim, 2003; and Naresh et al., 2012). Number of shoots $\mathrm{m}^{-}$ ${ }^{2}$ were not affected significantly due to different tillage practices at all the stages of crop growth. It increased progressively up- to $90^{\text {th }}$ days stage and thereafter, decreased at harvest (Wiatrak et al., 2004; Naresh et al., 2004; Ram Pravash, 2007; Naresh et al., 2012). This finding is supported by Pratik et al., (2002), Srivastva et al., (2002) Kumar et al., (2005), Prasad et al., (2005).

However, the highest grain yield, straw yield $\left(\mathrm{q} \mathrm{ha} \mathrm{h}^{-1}\right.$ ), and harvest index (\%) was observed under conventional tillage + sowing on beds $\left(\mathrm{T}_{3}\right)$ which was being at par with conventional tillage + sowing by seed cum ferti drill $\left(\mathrm{T}_{4}\right)$ 43.90 and $44.61 \mathrm{q} \mathrm{ha}^{-1}$ and reduced tillage + sowing by seed cum ferti drill $\left(\mathrm{T}_{2}\right) 42.64$ and $43.33 \mathrm{q} \mathrm{ha}^{-1}$ during both the years respectively. Similar research findings were also reported by Avtar et al., (2002), Asefa et al., (2004) Prasad et al., (2010) and Dhuka et al., (1992) (Table 1 and 2). 
Table.1 Effect of Tillage practices and moisture regime on growth, yield attributes and yield of wheat

\begin{tabular}{|c|c|c|c|c|c|c|c|c|c|c|c|c|c|c|}
\hline \multirow[t]{2}{*}{ Treatment } & \multicolumn{2}{|c|}{$\begin{array}{c}\text { Innitial plant } \\
\text { population }\left(\mathrm{m}^{-2}\right)\end{array}$} & \multicolumn{2}{|c|}{$\begin{array}{c}\text { Plant height }(\mathbf{c m}) \\
\text { At harvest }\end{array}$} & \multicolumn{2}{|c|}{$\begin{array}{c}\text { Number of shoots } \\
\left(\mathrm{m}^{-2}\right) \text { At harvest } \\
\text { stage }\end{array}$} & \multicolumn{2}{|c|}{$\begin{array}{c}\text { Dry matter } \\
\text { accumulation }\left(\mathrm{g} \mathrm{m}^{-2}\right) \\
\text { At harvest }\end{array}$} & \multicolumn{2}{|c|}{$\begin{array}{l}\text { Grain yield } \\
\qquad\left(\mathbf{q} \mathbf{h a}^{-1}\right)\end{array}$} & \multicolumn{2}{|c|}{$\begin{array}{l}\text { Straw yield } \\
\quad\left(\mathbf{q} \mathbf{h a}^{-1}\right)\end{array}$} & \multicolumn{2}{|c|}{$\begin{array}{c}\text { Harvest index } \\
(\%)\end{array}$} \\
\hline & $\begin{array}{l}2015- \\
16\end{array}$ & $\begin{array}{l}2016- \\
17\end{array}$ & $2015-16$ & $2016-17$ & $2015-16$ & 2016-17 & $2015-16$ & $2016-17$ & $\begin{array}{l}2015- \\
16\end{array}$ & $\begin{array}{l}2016- \\
17\end{array}$ & $\begin{array}{l}2015- \\
16\end{array}$ & $\begin{array}{l}2016- \\
17\end{array}$ & $\begin{array}{l}2015- \\
16\end{array}$ & $\begin{array}{l}2016- \\
17\end{array}$ \\
\hline \multicolumn{15}{|c|}{ Factor A: Tillage practices (Main plot) } \\
\hline $\mathbf{T}_{1}$ & 122.20 & 122.97 & 87.84 & 89.55 & 359.96 & 364.17 & 941.14 & 951.72 & 39.45 & 40.44 & 54.79 & 55.31 & 41.83 & 42.16 \\
\hline $\mathbf{T}_{2}$ & 125.30 & 126.16 & 95.15 & 97.02 & 395.56 & 398.44 & 1019.51 & 1031.05 & 42.64 & 43.33 & 58.66 & 59.10 & 42.09 & 42.30 \\
\hline $\mathbf{T}_{3^{-}}$ & 133.35 & 134.14 & 101.51 & 103.50 & 423.02 & 423.25 & 1087.63 & 1100.00 & 46.00 & 46.74 & 62.08 & 62.45 & 42.55 & 42.83 \\
\hline $\mathbf{T}_{4}$ & 128.28 & 128.68 & 97.61 & 99.53 & 404.60 & 407.43 & 1045.86 & 1057.72 & 43.90 & 44.61 & 59.98 & 60.56 & 42.27 & 42.39 \\
\hline SEm \pm & 2.28 & 2.59 & 1.80 & 1.84 & 7.57 & 7.66 & 19.66 & 19.56 & 1.10 & 1.03 & 1.51 & 1.49 & - & - \\
\hline CD at $5 \%$ & NS & NS & 6.25 & 6.37 & 26.19 & 26.51 & 68.03 & 67.69 & 3.81 & 3.58 & 5.24 & 5.16 & - & - \\
\hline \multicolumn{15}{|c|}{ Factor B:Moisture regimes (Sub plot) } \\
\hline $\mathbf{I}_{1}$ & 126.97 & 127.89 & 92.65 & 94.46 & 381.69 & 387.72 & 992.67 & 1003.88 & 40.27 & 41.20 & 55.63 & 56.45 & 41.98 & 42.17 \\
\hline $\mathbf{I}_{2}$ & 128.14 & 129.34 & 100.40 & 102.37 & 418.08 & 421.04 & 1075.71 & 1087.95 & 46.20 & 47.11 & 61.65 & 61.96 & 42.85 & 43.21 \\
\hline $\mathbf{I}_{3}$ & 127.34 & 128.04 & 100.01 & 101.98 & 417.11 & 416.33 & 1071.61 & 1083.77 & 45.48 & 45.97 & 61.64 & 61.82 & 42.46 & 42.64 \\
\hline $\mathbf{I}_{4}$ & 125.97 & 126.64 & 86.56 & 88.25 & 354.15 & 357.65 & 927.51 & 937.91 & 38.50 & 39.01 & 54.49 & 54.73 & 41.40 & 41.61 \\
\hline $\mathbf{I}_{5}$ & 127.26 & 128.00 & 98.01 & 99.94 & 408.01 & 408.77 & 1050.18 & 1062.10 & 44.53 & 45.60 & 60.97 & 61.81 & 42.23 & 42.47 \\
\hline SEm \pm & 2.31 & 2.28 & 1.68 & 1.72 & 7.06 & 7.09 & 18.24 & 18.25 & 0.72 & 0.75 & 1.01 & 1.02 & - & - \\
\hline CD at $5 \%$ & NS & NS & 4.92 & 5.01 & 20.61 & 20.69 & 53.24 & 53.27 & 2.094 & 2.20 & 2.95 & 2.97 & - & - \\
\hline
\end{tabular}


Table.2 Effect of tillage practices and moisture regime on nitrogen uptake, phosphorous and potassium uptake in grains, straw $\left(\mathrm{kg} \mathrm{ha}^{-1}\right)$ crop of wheat

\begin{tabular}{|c|c|c|c|c|c|c|c|c|c|c|c|c|}
\hline \multirow[t]{3}{*}{ Treatments } & \multicolumn{4}{|c|}{ Nitrogen uptake $\left(\mathrm{kg} \mathrm{ha}^{-1}\right)$} & \multicolumn{4}{|c|}{ Phosphorous uptake $\left(\mathrm{kg} \mathrm{ha}^{-1}\right)$} & \multicolumn{4}{|c|}{ Potassium uptake $\left(\mathrm{kg} \mathrm{ha}^{-1}\right)$} \\
\hline & \multicolumn{2}{|c|}{ Grains } & \multicolumn{2}{|c|}{ Straw } & \multicolumn{2}{|c|}{ Grains } & \multicolumn{2}{|c|}{ Straw } & \multicolumn{2}{|c|}{ Grains } & \multicolumn{2}{|c|}{ Straw } \\
\hline & $15-16$ & $16-17$ & $15-16$ & $16-17$ & $15-16$ & $16-17$ & $15-16$ & $16-17$ & $15-16$ & $16-17$ & $15-16$ & $16-17$ \\
\hline \multicolumn{13}{|c|}{ Factor A: Tillage practices (Main plot) } \\
\hline $\mathbf{T}_{1}$ & 60.03 & 61.59 & 28.52 & 28.80 & 14.07 & 14.68 & 6.46 & 6.84 & 13.68 & 14.29 & 76.97 & 78.20 \\
\hline $\mathbf{T}_{2}$ & 66.00 & 67.12 & 31.06 & 31.27 & 15.77 & 16.46 & 7.03 & 7.43 & 15.33 & 16.01 & 83.74 & 85.02 \\
\hline $\mathbf{T}_{\mathbf{3}}$ & 72.04 & 73.20 & 33.23 & 33.40 & 17.19 & 17.95 & 7.52 & 7.95 & 16.73 & 17.47 & 89.67 & 90.77 \\
\hline $\mathbf{T}_{4}$ & 68.20 & 69.27 & 31.90 & 32.19 & 16.29 & 16.99 & 7.22 & 7.65 & 15.84 & 16.54 & 86.01 & 87.43 \\
\hline $\mathrm{SEm} \pm$ & 2.032 & 1.794 & 0.92 & 0.89 & 0.44 & 0.45 & 0.22 & 0.19 & 0.36 & 0.34 & 2.26 & 2.15 \\
\hline CD at $5 \%$ & 7.03 & 6.21 & 3.17 & 3.09 & 1.51 & 1.55 & 0.77 & 0.68 & 1.26 & 1.17 & 7.82 & 7.47 \\
\hline \multicolumn{13}{|c|}{ Factor B:Moisture regimes (Sub plot) } \\
\hline $\mathbf{I}_{1}$ & 62.35 & 63.80 & 29.45 & 29.85 & 14.90 & 15.64 & 6.67 & 14.90 & 14.46 & 15.22 & 79.45 & 81.12 \\
\hline $\mathbf{I}_{2}$ & 72.64 & 74.03 & 33.15 & 33.32 & 17.21 & 17.90 & 7.50 & 17.21 & 16.75 & 17.43 & 89.42 & 90.53 \\
\hline $\mathbf{I}_{3}$ & 71.07 & 71.94 & 32.98 & 33.06 & 16.99 & 17.65 & 7.47 & 16.99 & 16.52 & 17.18 & 88.98 & 89.83 \\
\hline $\mathbf{I}_{4}$ & 58.50 & 59.27 & 28.33 & 28.42 & 13.86 & 14.42 & 6.41 & 13.86 & 13.48 & 14.04 & 76.39 & 77.26 \\
\hline $\mathbf{I}_{5}$ & 68.28 & 69.94 & 31.97 & 32.41 & 16.19 & 16.98 & 7.24 & 16.19 & 15.75 & 16.52 & 86.24 & 88.04 \\
\hline SEm \pm & 1.10 & 1.36 & 0.68 & 0.56 & 0.33 & 0.35 & 0.14 & 0.33 & 0.26 & 0.32 & 1.75 & 1.69 \\
\hline CD at $5 \%$ & 3.21 & 3.98 & 2.00 & 1.65 & 0.97 & 1.03 & 0.40 & 0.97 & 0.77 & 0.93 & 5.12 & 4.93 \\
\hline
\end{tabular}


Effect of tillage practices on nutrient uptake

The highest nitrogen, phosphorous and potassium uptake $\mathrm{kg} \mathrm{ha}^{-1}$, was recoded under conventional tillage + sowing on beds $\left(\mathrm{T}_{3}\right)$ in grains, straw which was being at par with conventional tillage + sowing by seed cum ferti drill $\left(\mathrm{T}_{4}\right)$ and reduced tillage + sowing by seed cum ferti drill $\left(\mathrm{T}_{2}\right)$, respectively. Although, the lowest nitrogen uptake in grains, straw grains, straw was recorded under zero tollage $\left(T_{1}\right)$ during both of the years of investigation (Singh et al., 1975; Singh and Seath, 1978; Singh and Seath, 1978 and Dighe et al., 1978).

\section{Effect of moisture regimes on growth and yield}

Various levels of moisture regimes affected the growth of wheat i.e. plant population plants $\mathrm{m}^{-2}$, plant height $(\mathrm{cm})$ at harvest stage, Number of shoots $\mathrm{m}^{-2}$ at harvest stage and dry matter accumulation $\left(\mathrm{gm} \mathrm{m}^{-2}\right)$ at harvest stage significant was recorded under treatment 1.0 IW/CPE $\left(\mathrm{I}_{2}\right)$ which at par with $1.2 \mathrm{IW} / \mathrm{CPE}$ and 5 irrigation each at CRI, tillering, late jointing, flowering and milking stage $\left(\mathrm{I}_{5}\right)$ respectively. Though, the minimum were observed with 3 irrigation each at CRI, late jointing and milking stage $\left(\mathrm{I}_{4}\right)$ during both the years 2015-16 and 2016-17 respectively. This might be due to increase in plant height, and uptake of nutrients through adequate irrigation supply. All these contributed for full turgidity and opened leaves, which increased the photosynthetic activity of crops, resulting in higher dry matter accumulation (Rahman et al., 2000; Saren et al., 2004). Similar trend was found also reported by Rahman et al., (2002), Prashar and Thaman (2005), Khatri et al., (2002).

Highest grain yield, straw yield $\left(\mathrm{q} \mathrm{ha}^{-1}\right)$ was recorded under irrigation at $1.0 \mathrm{IW} / \mathrm{CPE}\left(\mathrm{I}_{4}\right)$ which at par with $1.2 \mathrm{IW} / \mathrm{CPE}\left(\mathrm{I}_{3}\right)$ and 5 irrigation each at CRI, tillering, late jointing, flowering and milking stage $\left(\mathrm{I}_{5}\right)$ respectively. This might be due to adequate moisture availability, which contributed to better growth parameter and yield attributes. The finding is supported by Khatri et al., (2002). Similar research findings were also reported by Nadeem et al., (2007) and Behera and Sharma (2014).

\section{Effect of moisture regimes on nutrient uptake}

The highest nitrogen, phosphorous and potassium uptake $\left(\mathrm{kg} \mathrm{ha}^{-1}\right)$ was recorded in 1.0 IW/CPE ratio $\left(\mathrm{I}_{2}\right)$ in grains, straw which being at par with $\left(\mathrm{I}_{3}\right)$ and 5 irrigation each at CRI, tillering, late jointing, flowering and milking stage $\left(\mathrm{I}_{5}\right)$ moisture regime while the lowest nitrogen uptake was observed under the 3 irrigation each at CRI, late jointing and milking stage $\left(\mathrm{I}_{4}\right)$ during both the years of investigation.

On the basis of experimental findings, it can be concluded that the conventional tillage + sowing on beds $\left(T_{3}\right)$ provide suitable to be better for growth and development, yield and nutrient uptake of timely sown wheat. Thus, the irrigation scheduling at moisture regime under the treatment $1.0 \mathrm{IW} / \mathrm{CPE} \quad\left(\mathrm{I}_{2}\right) \quad(6$ irrigations) seem to provide for suitable and adequate moisture supply to be better growth, photosynthetic activity, development, yield and uptake of nutrients through adequate irrigation supply in wheat.

\section{References}

Anonymous. (1995). Tillage Systems in Tropics: Management Options and Sustainability Implications, in: R. Lal (Ed.), FAO. Soils Bulletin, 71: 107-120.

Asefa, T., Tanner, D. and Bennie, A.T.P. (2004). Effects of stubble management, 
tillage and cropping sequence on wheat production in the south-eastern highlands of Ethopia. Soil and Tillage Research, 76(1): 69-82.

Avtar; Mahey, R. K., Singh, O., Brar, S. S., Virk, A. S. and Singh, J. 2002. Effect of first, subsequent irrigation (s) and tillage on grain yield, nutrients uptake, rooting density of wheat, soil moisture content, consumptive use and water use efficiency. Res. on Crops, 3(1): 1-10.

Behera, U. K. and Sharma, A.R. 2014. Productivity and water use efficiency of wheat (Triticum aestivum) under different resource conservation techniques and irrigation regimes. Cereal Res. Communications, 42(3): 439-449.

Bhushan, L., Ladha, J.K., Gupta, R.K., Singh, S., Tirol-Padre A., Saharawat, Y.S., Gathala, M. and Pathak, H. 2007. Saving of water and labor in a ricewheat system with no tillage and direct seeding technologies. Agronomy Journal 99: 1288-1296.

Coughlan, K.J., Smith, G.D., and Yule, D.F. 1989. Soil physical research for improved dry land crop production in Vertisols in Queensland, Australia. In: In Management of Vertisols for improved agricultural production. Proceeding of an IBSRAM Inaugural Workshop, ICRISAT, India. Pp. 18-22.

Dhuka, A.K., Sadaria, S.G., Patel, J.G. and Patel, B.S. 1992. Effect of rate and time of $\mathrm{N}$ application on late sown wheat. Indian J. Agron., 37 (2): 354-55.

Directorate of Economics and Statistics, Ministry of agriculture and farmers Welfare, India, 2016.

Gupta, R.K and Seth, A. 2007. A review of resource conservation technologies for sustainable management of the ricewheat system cropping systems of the Indo- Gangetic Plains. Crop Protection 26: 436-447.
Hira, G.S. 2009. Water management in northern states and the food security of India. Journal of Crop Improvement 23: 136-157.

Idnani, L. K. and Kumar, A. 2012. Relative efficiency of different.; irrigation schedules for conventional, ridge and raised bed seeding of wheat (Triticum aestivum). Indian J. of Agro., 57(2): 148-151.

Ishaq, M., Ibrahim, M. and Lal, R. 2003. Tillage and fertilizers effects on root growth of wheat and cotton on a sandy loam in Pakistan. Journal of Sustainable Agriculture, 22(1): 167-176.

Jackson, M.L. 1967. Soil chemical analysis. Prentice hall of India, Private Limited, New Delhi, Pp. 183.

Khatri, R. S., Goel, A. C. and Malik, R. K. 2001. Consumptive use and soil moisture depletion pattern in bed and flat sowing ofwheat in rice-wheat system under different irrigation levels. Inte. J. Tropical Agri., 18(3): 259-264.

Nadeem, M. A., Tanveer, A., Ali, A., Ayub, M. and Tahir, M. 2007. Effect of weedcontrol practice and irrigation levels on weeds and yield of wheat (Triticum aestivum). Indian J. of Agro., 52(1): 6063.

Naresh, R. K., Singh, B., Singh, S. P., Singh, P. K., Arvind Kumar and Amit Kumar, 2012. Furrow Irrigated Raised Bed (FIRB) planting technique for diversification of rice-wheat system for Western IGP region. International Journal of Life Sciences Biotechnology and Pharma Res., 1(3):134-141.

Naresh, R.K., Singh, S.P., Dwivedi, Ashish, Sepat, Naval Kishor, Kumar, Vineet., Kumar, Ronaliya Lalit., Kumar, Vikas and Singh, Rachna. 2013. Conservation Agriculture improving soil quality for sustainable production systems under smallholder farming conditions in North West India: A Review. International 
Journal of Sciences of Life Sciences Biotechnology and Pharma Research 2(4): 151-213.

Olsen, S.R., Cok, C.V., Watanabe, P.C. and Dean, L.A. 1954. Estimation of phosphorus in soils by extraction with di-sodium carbonate. U.S.D.A. circular. 34, 939, 1-19 U.S. Government Printing Office, Washington D.C.

Prasad, S., Singh, Y., Singh, R.P. and Singh, G. 2005. Effect of crop establishment, weed control method and time of nitrogen application on late-sown wheat. Indian journal of weed science 37(1, 2): 93-95.

Pratik; Satya; Chowdhury, S and Tomar, S. M. S. 2002. Path coefficient analysis of agronomic characters affecting grain yield in wheat (Triticum aestivum L.) under furrow-irrigated raised bed (FIRB) planting system. Annals of Agri. Res., 23(2): 248-255.

Prihar, S.S. and Khepar, S.D. 1997. Resource management for sustainable intensive agriculture- water. Proc. Third
Agricultural Science Congress, National Academy of Agricultural Sciences, Ludhiana, Punjab. Pp. 91-101.

Rehman, M.A., Karim, A.J.M.S., Haque, M.M. and Eqashira, K. 2000. Effect of irrigation and nitrogen fertilization on plant growth and root characteristics of wheat on a clay terrace soil of Bangladesh. J. Faculty of Agric. 45 (1): 301-308.

Singh, R.P. and Seth, J. 1978. Nitrogen uptake and potential of production dry matter in dwarf wheat as influenced by soil and foliar application of nitrogen, Indian J. Agric., Sci., 48 (6): 342-46.

Subbaih B.V and Asija G. L. 1956. A rapid procedure for determination of available nitrogen in soil. Current Sci., 25: 259260.

USDA, 2017. World Agriculture Production. Pp: $1-30$.

Wiatrak, P.J., Wright, D.L. and Marois. 2004. Tillage and residual nitrogen impact on wheat forage. Agronomy journal 96 (6): 1761-1764.

\section{How to cite this article:}

Vinay Kumar Pandey, B.N. Singh, Manoj Kumar, Shrimannarayan Dubey, Vipul Singh, Deepak Pandey and Ajit Kumar. 2019. Effect of Tillage Practices and Moisture Regimes on the Performance of Growth, Yield and Nutrient Uptake of Timely Sown Wheat (Triticum aestivum L.). Int.J.Curr.Microbiol.App.Sci. 8(03): 2368-2375. doi: https://doi.org/10.20546/ijcmas.2019.803.280 